\title{
Erratum to: IFN-gamma signaling in the central nervous system controls the course of experimental autoimmune encephalomyelitis independently of the localization and composition of inflammatory foci
}

Eunyoung Lee ${ }^{1,2}$, Sarah Chamanara ${ }^{1}$, David Pleasure ${ }^{1,3}$ and Athena M. Soulika $a^{1,2^{*}}$

\section{Erratum}

Upon publication of the original article [1], it was noticed that Sarah Chamanara's name was incorrectly written as 'Sarah Chanamara'. This has now been corrected in this erratum.

\footnotetext{
Author details

${ }^{1}$ Institute for Pediatric Regenerative Medicine, Shriners Hospitals for Children Northern California, Sacramento, CA 95817, USA. ${ }^{2}$ Department of Dermatology, School of Medicine, University of California, Davis Sacramento, CA 95816, USA. ${ }^{3}$ The Department of Neurology, School of Medicine,

University of California Davis, Sacramento, CA 95817, USA.
}

Received: 22 August 2016 Accepted: 22 August 2016

Published online: 30 August 2016

\section{Reference}

1. Lee E, Chamanara S, Pleasure D, Soulika AM. IFN-gamma signaling in the central nervous system controls the course of experimental autoimmune encephalomyelitis independently of the localization and composition of inflammatory foci. J Neuroinflammation. 2012;9:7.

\footnotetext{
*Correspondence: athena.soulika@ucdmc.ucdavis.edu

${ }^{1}$ Institute for Pediatric Regenerative Medicine, Shriners Hospitals for Children Northern California, Sacramento, CA 95817, USA

2Department of Dermatology, School of Medicine, University of California, Davis Sacramento, CA 95816, USA

Full list of author information is available at the end of the article
}

Submit your next manuscript to BioMed Central and we will help you at every step:

- We accept pre-submission inquiries

- Our selector tool helps you to find the most relevant journal

- We provide round the clock customer support

- Convenient online submission

- Thorough peer review

- Inclusion in PubMed and all major indexing services

- Maximum visibility for your research

Submit your manuscript at www.biomedcentral.com/submit 